\title{
Er det håp for skandinavismen?
}

\author{
Schaffalitzky de Muckadell OB, Haunsø S \\ Vilstrup $\mathrm{H}$, red. \\ Medicinsk kompendium \\ 17. utg. 2989 s, tab, ill, 2 bd. København: \\ Nyt Nordisk Forlag Arnold Busck, 2009 \\ Pris DKK 3995 \\ ISBN 978-87-17-03933-9
}

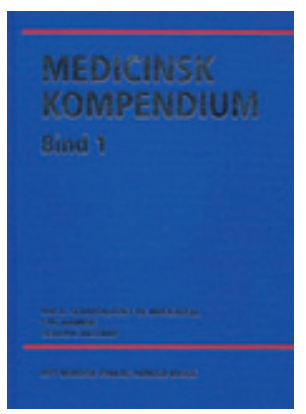

«Klein har ringet og sagt at en anden har tilbudt at lave et medicinsk kompendium. Men vi får det hvis vi vil have det. Jeg mener vi laver det, ikke?» (1). Slik lyder en bemerkning i et brev datert 30. januar 1934 fra den nyutdannede medisinske kandidat Erik Hagens (1909-44) til barndomsvennen Ole Bernth (1907-99), som på det tidspunktet fortsatt var medisinstudent. De to hadde allerede forut for dette revidert en lærebok i farmakologi for forleggeren Hugo Klein i Store Nordiske Videnskabsboghandel i København. Nå var de åpenbart klare for større oppgaver. Muligens ble beslutningen fattet $i$ et anfall av ungdommelig overmot, og man kan vel ane at Hagens hadde ønsket seg mer tid til å nyte livets goder når han et drøyt halvår senere skriver: «Nu er jeg i Farum. Praxis er meget stor, lægen (Castberg) bebor en stor herskabelig villa, har rideheste, chauffør, tennisbane; det er en yderst behagelig tilværelse [...] Jeg håber at kunne få gjort en del ved bogen; jeg har meget svært ved at ramme stilen; hidtil aner jeg kun dunkelt hvordan den skal blive.» (1). Etter dette må det imidlertid ha blitt fart over skrivearbeidet, for året etter kom Medicinsk kompendium i sin første utgave på 481 sider, «udarbeidet paa grundlag af forelæsningsnoter fra de senere semestre» (2).

74 år og 17 utgaver senere utgjør de to bindene til sammen nesten 3000 sider. Men mens sidetallet tross alt ikke har økt med mer enn en faktor på drøyt seks, har antall forfattere blitt 81-doblet, fra to til 162 . Vi har lest $i$ verket med øynene til en universitetslærer i geriatri og generell indremedisin (TBW) og en medisinstudent drøyt halvveis i studiet (TEW), og vi har begge fors $ø$ kt å lese om emner vi synes vi kan godt og om emner vi gjerne skulle lært mer om. Det har gitt både opp- og nedturer.

\section{Struktur i smått, men ikke i stort}

Hvert enkelt av de 75 kapitlene har stort sett en forbilledlig strukturert disposisjon, som gjør det lett å finne frem og som hjelper godt på kunnskapstilegnelsen. Forfatterne av de kliniske kapitlene har åpenbart fått en nokså klar mal å følge for hver tilstand som omtales. Den er helt tradisjonell, med små variasjoner over en grunnstruktur bestående av definisjon - forekomst - årsaker - patogenese - symptomer - kliniske funn - parakliniske funn - forløp - differensialdiagnoser - behandling. Dette er en stor fordel og gjør det lett å finne relevant informasjon så sant man vet hvilken sykdom man skal slå opp på. Illustrasjonene er fine (fig 1), og bidrar klart til å lette innlæringen.

På overordnet nivå er strukturen dessverre ikke like god. Slår man opp på «feber» i registeret, ledes man til et kapittel om hypertermi, ikke til infeksjonsdelen. For å komme dit, må man slå opp på «feber av ukjent årsak». I hovedavsnittet om hjertesykdommer finner man emner som «pasienten med dyspné» og «pasienten med brystsmerter», mens «dyspné» og «brystsmerter» på sin side er emner i hovedavsnittet om lungesykdommer. Synkope har et eget kapittel (sammen med hypotensjon), men er også et avsnitt i kapitlet om hjertesykdommer. Inndelingen i kapitler og underavsnitt er heller ikke konsekvent. Et kapittel med tittel «fordøyelseskanalens sykdommer» etterfølges av suksessive kapitler om munnhulesykdommer, oesophagussykdommer, sykdommer i ventrikkel og duodenum osv. Mens gastroenterologien og endokrinologien er splittet opp i hhv. sju og ti kapitler, er kardiologien, lungemedisinen, nefrologien og nevrologien pakket sammen til ett kapittel hver - rimeligvis temmelig store og med et stort antall forfattere innen hvert kapittel.

På mange måter er nok denne fragmenteringen (sammen med den nærmest hemningsløse inflasjonen i antall forfattere) symptomatisk for den fragmenteringen indremedisinen har gjennomgått $\mathrm{i}$ de 74 årene siden Medicinsk kompendium utkom første gang. Her skriver hver kvistspesialist om sin organelle, mens forsøkene på helhetsperspektiv sammenlikningsvis blir fattigslige. Rett nok finnes innledende kapitler om kliniske kardinalmanifestasjoner som smerte, væske- og elektrolyttforstyrrelser osv, og de store organkapitlene avsluttes med egne avsnitt om problemorientert diagnostisk utredning. Disse avsnittene kommer likevel ikke godt nok i møte det behov man som lege har når man står overfor en pasient med et symptom snarere enn en ferdig diagnose, fordi de ikke i tilstrekkelig grad trekker forbindelsene på tvers av kapitlene. Heller ikke får man så mye bistand når man - slik hverdagen i medisinske avdelinger i regelen er - skal forsøke å hjelpe pasienter som ikke feiler én men mange ting, og som i tillegg er preget av varierende aldersforandringer og kronisk organsvikt. Akutt funksjonssvikt - en av de vanligste av alle de kliniske kardinalmanifestasjonene - er knapt viet en bemerkning, og omtalen av delirium - som foreligger ved innleggelsen i medisinske avdelinger hos minst $20 \%$ av pasientene over 65 år (3) - er bare så vidt nevnt. Slik sett kan man kanskje si at Medicinsk kompendium viderefører den ignoransen overfor eldre og pasienter med sammensatte medisinske problemer som har fått prege store deler av sykehusmedisinen i årtier.

\section{Erfaringsbasert eller evidensbasert?}

Allerede i forordet anføres at alle kliniske beslutninger i prinsippet bør være evidensbaserte. Dette ga oss bange anelser. Ikke fordi vi ikke anerkjenner den evidensbaserte medisinens store betydning, men fordi evidenstyranniet nå har tatt overhånd og bl.a. har satt den erfaringsbaserte kunnskap i uberettiget vanry. Ikke minst i lærebøker kan det bli temmelig slitsomt når selv det mest trivielle utsagn (f.eks. at man tenderer til å få mer rynker med alderen) må belegges med opptil flere referanser (4). Nettopp i det digitale mylderet av randomiserte fors $ø$, metaanalyser og mer eller mindre statsautoriserte prosedyresnekkere, kan den tradisjonelle papirbaserte læreboken få sin renessanse ved at den filtrerer evidensen gjennom forfatternes sunne skjønn og kliniske erfaring. Det var derfor med lettelse vi kunne konstatere at forfatterne av Medicinsk kompendium ikke lever opp til sitt eget forsett på dette punktet. 

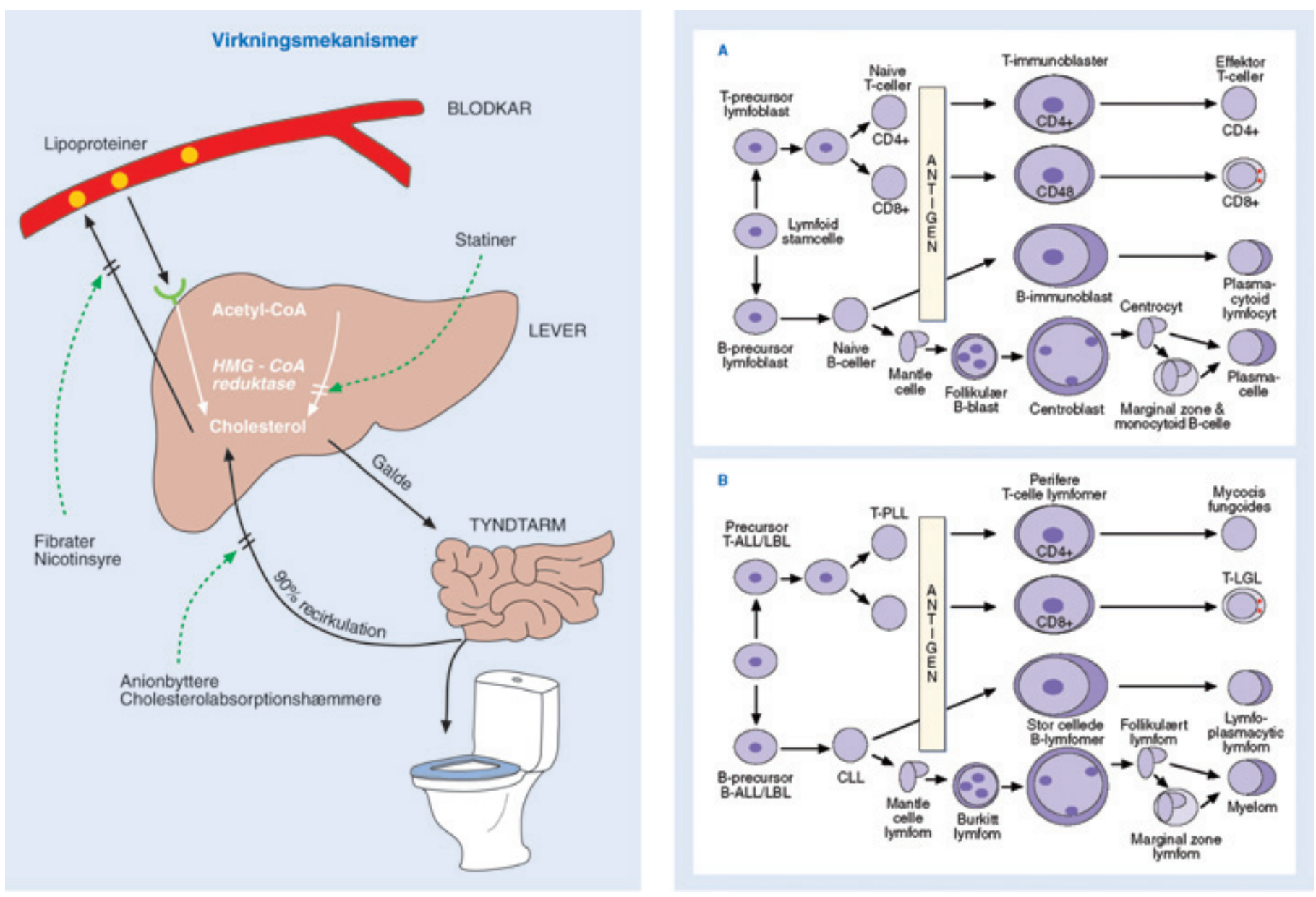

Figur 1 Figurer fra boken. Gjengitt med tillatelse

Det er åpenbart at de råd forfatterne gir, er en syntese av strikt evidens og deres egen og fagmiljøets akkumulerte erfaring. Litteraturreferansene er få, men åpenbart grundig utvalgt. Slik det bør være. Et (noe paradoksalt) pluss her, altså!

\section{Hvor bredt perspektiv?}

Avgrensningen av stofftilfanget i lærebøker volder ofte problemer. Medicinsk kompendium omfatter over 90 sider generell patologi (her kalt biologiske grunnbegreper), 18 sider sosialmedisin og forebyggende medisin, 25 sider yrkesmedisin, sju sider rettsmedisin, fem sider rettspsykiatri og fem sider om akutte psykoser, for bare å nevne noen av emnene man vanligvis ikke forventer å finne i en lærebok i klinisk indremedisin. Emnene kan være viktige nok, og de respektive kapitlene er også leseverdige. Likevel er vi usikre på om det er hensiktsmessig å favne så bredt $i$ et verk som dette. Alt bidrar til å gi verket dets temmelig kompakte preg, samtidig som omtalen av slike emner vanskelig kan bli fyllestgjørende. Man slipper neppe unna å kjøpe lærebøker i flere av disse emnene selv om man skulle være innehaver av Medicinsk kompendium. Verket ville altså vunnet på å skalle av kapitler i randsonen av sitt hovedfokus, blitt et par hundre sider tynnere og samtidig kanskje hevet ambisjonsnivået ytterligere når det gjelder omtalen av den klassiske indremedisinske kliniske praksis.

\section{Skandinavistisk \\ eller angloamerikansk?}

Et skandinaviskspråklig medisinsk standardverk tiltaler oss som har sans for å hegne om den skandinaviske enhetskulturen. Medicinsk kompendium er skrevet på et lettlest dansk. Selv om nordmenn kanskje må ta et par linjer om igjen når de kommer til begreper som «udskillelsen av brintioner i den raske nyre», så føles det behagelig å lese dette verket. At dansk behandlingstradisjon og organiseringen av det danske helsevesenet ligger nær opptil det vi er vant til i Norge, er også en stor fordel. Likevel har verket et omfang og et ambisjonsnivå som gjør at forfatterne må finne seg $\mathrm{i} a ̊$ bli sammenliknet med engelskspråklige mesterverk som f.eks. Harrison's principles of internal medicine (5). Da når de dessverre ikke helt opp. Hertil kommer at mens det rimeligste tilbudet vi fant på Medicinsk kompendium var på kr 3 755, kan man få kjøpt Harrison's for omtrent $750 \mathrm{kr}$. Velger man det, har man råd til å supplere med noen av de helnorske lærebøkene som spesifikt tar for seg én indremedisinsk grenspesialitet (6-10), og som alle er skrevet av én eller noen få forfatteremed de fordelene det gir for struktur og indre konsistens. Vi tror det må bli vårt førstevalg enten man ser det fra studentens, fastlegens eller sykehuslegens perspektiv.

\section{Torgeir Bruun Wyller}

Geriatrisk avdeling

Oslo universitetssykehus, Ullevål

\section{Tuva Elisabeth Wyller}

Det medisinske fakultet, Universitetet i Oslo

\section{Litteratur}

1. Kardel T. Medicinsk Kompendium 1935-2000 Ugeskr Læger 2000; 162: 2006-8. www.ugeskriftet.dk/lf/UFL/ufl99 00/smid_ud/ ufl2051/v p/35388.htm (7.12.2009).

2. Hem E. Medisinsk kompendium med tyngde. Anmeldelse av: Hansen NE, Haunsø S, Schaffalitzky de Muckadell OB, red. Medicinsk kompendium. Tidsskr Nor Lægeforen 2004: 124: 2148.

3. Inouye SK. Delirium in older persons. N Engl J Med 2006; 354: 1157-65

4. Wyller TB. Geriatrisk murstein. Anmeldelse av: Cassel CK, Leipzig RM, Cohen HJ, red. Geriatric medicine. An evidence-based approach. Tidsskr Nor Lægeforen 2004; 124: $2391-2$.

5. Fauci AS, Braunwald E, Kasper DL et al, red. Harrison's principles of internal medicine. 17. utg New York, NY: McGraw-Hill, 2008.

6. Hartmann A, Jenssen T, Julsrud J. Nyremedisin en praktisk veileder. 2. utg. Oslo: Gyldendal Akademisk, 2008

7. Gulsvik A, Bakke PS. Lungesykdommer. En basal innføring. Bergen: Fagbokforlaget, 2004

8. Giæver P. Lungesykdommer. 2. utg. Oslo: Universitetsforlaget, 2008

9. Laake K. Geriatri i praksis. 4. utg. Oslo: Gyldendal Akademisk, 2003.

10. Evensen SA, Brinch L, Tjønnfjord GE, red. Blodsykdommer. 6. utg. Oslo: Gyldendal Akademisk, 2008. 